\title{
Determination of acidic catecholamine metabolites in plasma and cerebrospinal fluid using gas chromatography-negative- ion mass spectrometry
}

\author{
Citation for published version (APA): \\ Jong, de, A. P. J. M., Kok, R. M., Cramers, C. A. M. G., \& Wadman, S. K. (1986). Determination of acidic \\ catecholamine metabolites in plasma and cerebrospinal fluid using gas chromatography-negative-ion mass \\ spectrometry. Journal of Chromatography. Biomedical Applications, 382(1), 19-30. \\ https://doi.org/10.1016/S0378-4347(00)83501-X
}

DOI:

10.1016/S0378-4347(00)83501-X

Document status and date:

Published: 01/01/1986

\section{Document Version:}

Publisher's PDF, also known as Version of Record (includes final page, issue and volume numbers)

\section{Please check the document version of this publication:}

- A submitted manuscript is the version of the article upon submission and before peer-review. There can be important differences between the submitted version and the official published version of record. People interested in the research are advised to contact the author for the final version of the publication, or visit the DOI to the publisher's website.

- The final author version and the galley proof are versions of the publication after peer review.

- The final published version features the final layout of the paper including the volume, issue and page numbers.

Link to publication

\footnotetext{
General rights

- You may freely distribute the URL identifying the publication in the public portal. follow below link for the End User Agreement:

www.tue.nl/taverne

\section{Take down policy}

If you believe that this document breaches copyright please contact us at:

openaccess@tue.nl

providing details and we will investigate your claim.
}

Copyright and moral rights for the publications made accessible in the public portal are retained by the authors and/or other copyright owners and it is a condition of accessing publications that users recognise and abide by the legal requirements associated with these rights.

- Users may download and print one copy of any publication from the public portal for the purpose of private study or research.

- You may not further distribute the material or use it for any profit-making activity or commercial gain

If the publication is distributed under the terms of Article $25 \mathrm{fa}$ of the Dutch Copyright Act, indicated by the "Taverne" license above, please 
Journal of Chromatography, 382 (1986) 19-30

Biomedical Applications

Elsevier Science Publishers B.V., Amsterdam - Printed in The Netherlands

CHROMBIO. 3271

DETERMINATION OF ACIDIC CATECHOLAMINE METABOLITES IN

PLASMA AND CEREBROSPINAL FLUID USING GAS

CHROMATOGRAPHY-NEGATIVE-ION MASS SPECTROMETRY

\section{A.P.J.M. DE JONG* and R.M. KOK}

Department of Pediatrics, Free University Hospital, De Boelelaan 1117, $1007 \mathrm{MB}$ Amsterdam (The Netherlands)

\section{C.A. CRAMERS}

Department of Instrumental Analysis, Eindhoven University of Technology, P.O. Box 513, 5300 MB Eindhoven (The Netherlands)

and

\section{S.K. WADMAN}

University Children's Hospital "Het Wilhelmina Kinderziekenhuis", Nieuwe Gracht 137, 3512 LK Utrecht (The Netherlands)

(First received January 31st, 1986; revised manuscript received May 7th, 1986)

SUMMARY

A method for the assay of acidic catecholamine metabolites in biological fluids using capillary gas chromatography-electron-capture negative-ion mass spectrometry is described. The method combines acetylation of phenolic hydroxy groups in buffered aqueous solution followed by pentafluorobenzyl ester formation and acetylation of aliphatic hydroxy groups under anhydrous conditions. The resulting per-O-acetyl carboxypentafluorobenzyl esters provided excellent negative-ion mass spectra with intense and diagnostic anions. The sensitivity of the analysis using electron-capture negative-ion mass spectrometry exceeds that using electron-impact mass spectrometry by two to three orders of magnitude. Analysis of acidic catecholamine metabolites in human lumbar cerebrospinal fluid and plasma were performed with good precision $\left(\sigma_{\text {rel }}<5 \%\right)$ at the low nanomoles per litre level. 


\section{INTRODUCTION}

Catecholamines (CA) and their metabolites are of considerable interest in neurological research [1], in clinical diagnosis [2] and in stress-related problems. Catecholamines exert their role primarily as neurotransmitters. The concentrations of these amines and most of the metabolites are normally at the low nanomoles per litre level in plasma and cerebrospinal fluid (CSF) [3].

Various methods have been developed to measure these compounds. Methods employing gas chromatography-mass spectrometry (GC-MS) have proved to be most specific and sensitive. Faull and Barchas [4] have recently reviewed this topic. They summarized several derivatization methods for acidic CA metabolites two of which were suitable for GC-electron-capture negative-ion MS (EC-NIMS). The recent highly sensitive MS technique might be of particular value for the determination of CA and associated metabolites in plasma and CSF. Shimamura et al. [5] reported its application to the determination of trace amounts of labelled isomers of some CA metabolites in urine. EC-NIMS, however, is a less universal technique than the classical electron-impact (EI) and positive-ion chemical-ionization (PICI) MS methods. A limiting condition in using GC-EC-NIMS is the relatively small dynamic range. Owing to exhaustion of thermal electrons in the ion source, a non-linear response might be obtained if large amounts of compounds with electron affinity co-elute with the compound of interest. The potential utility of GC-EC-NIMS has become recognized in biomedical research, as revealed from recent publications [6-13].

In this paper we report a sensitive assay for acidic CA metabolites in biological fluids by GC-EC-NIMS. Basically, the method combines two convenient chemical treatments, providing suitable derivatives in high yields. First, the phenolic hydroxy groups were acetylated in aqueous solution [14-17] and subsequently extracted with an organic solvent. This method facilitates an efficient extraction and improves the selectivity because extractions were accomplished from a less acidic aqueous sample than that generally used [2]. Secondly, the acetyl derivatives were converted into their pentafluorobenzyl esters (PFB), providing an excellent electrophore for EC-NIMS analysis [7, 9]. Non-acetylated aliphatic hydroxy groups were subsequently acetylated under anhydrous conditions. The final products, the per-O-acetylcarboxy-PFB derivatives (AC-PFB) were stable, volatile and highly electronegative compounds, making reliable determinations of acidic $\mathrm{CA}$ metabolites at the nanomoles per litre level possible using GC-EC-NIMS.

\section{EXPERIMENTAL}

Gas chromatography-mass spectrometry

GC-MS experiments were performed using a Kratos MS-80 instrument (Kratos, Manchester, U.K.) with negative-ion detection capability. The instrument was operated at a resolution $R=1000$ (10\% valley definition). The moderating gas for EC-NIMS was ammonia. Ionization was initiated with $50-80 \mathrm{eV}$ electrons with an emission current of $1.5 \mathrm{~mA}$. The source temperature was $225^{\circ} \mathrm{C}$ unless indicated otherwise. The chromatographic 
column was a CPSIL-19 chemical bonded fused-silica capillary, $20 \mathrm{~m} \times 0.22$ $\mathrm{mm}$ I.D. (Chrompack, Middelburg, The Netherlands). Helium was used as the carrier gas with a flow-rate of $0.55 \mathrm{ml} \mathrm{min}^{-1}$. The oven temperature was increased from its initial temperature of $260^{\circ} \mathrm{C} 2 \mathrm{~min}$ after injection at a rate of $5^{\circ} \mathrm{C} \mathrm{m^{-1 }}$ to $300^{\circ} \mathrm{C}$. The injection temperature was $300^{\circ} \mathrm{C}$ and the $\mathrm{GC}-\mathrm{MS}$ interface was maintained at $260^{\circ} \mathrm{C}$. Samples were introduced using a solid injector system (glass falling needle, Chrompack [18]). The capillary column was inserted directly into the ion source as described previously [19].

\section{Materials and reagents}

Homovanillic acid (HVA), vanillylmandelic acid (VMA), dihydroxyphenylacetic acid (DOPAC) and dihydroxymandelic acid (DOMA) were obtained from Janssen Pharmaceutica (Beerse, Belgium) and vanillyllactic acid sodium salt (VLA) from Sigma (St. Louis, MO, U.S.A.).

Acetic anhydride (AA), triethylamine (TEA), deuterium oxide $\left({ }^{2} \mathrm{H}_{2} \mathrm{O}\right)$ and deuterium chloride $\left({ }^{2} \mathrm{HCl}\right)$ were purchased from Merck (Darmstadt, F.R.G.).

Buffers. The buffers used were phosphate buffer $\left(1 M \mathrm{~K}_{2} \mathrm{HPO}_{4}\right.$, the $\mathrm{pH}$ adjusted with concentrated phosphoric acid to 7.7) and phosphate-carbonate buffer ( $1 M \mathrm{~K}_{2} \mathrm{HPO}_{4}$ mixed with a saturated $\mathrm{K}_{2} \mathrm{CO}_{3}$ solution $1: 1$ by volume and the $\mathrm{pH}$ adjusted to 10.5 with concentrated phosphoric acid).

\section{Synthesis of deuterium-labelled internal standards}

Ring-deuterated 2,5,6- ${ }^{2} \mathrm{H}_{3}$ isomers of HVA (HVA-d ${ }_{3}$ ), DOPAC (DOPAC-d $\mathrm{d}_{3}$ ) and VLA (VLA- $d_{3}$ ) were synthesized according to the method of Muskiet et al. [20] . [2,5,6- $\left.{ }^{2} \mathrm{H}_{3}\right]$ VMA (VMA- $\mathrm{d}_{3}$ ) was obtained from Mass Analys (Bromma, Sweden). All deuterated isomers contained less than $1 \%$ of the parent compounds.

\section{Analytical system}

A scheme of the analytical system is presented in Fig. 1.

\section{Plasma pre-treatment}

For the separation of CA metabolites from interfering phenylalanine, plasma samples $(1 \mathrm{ml})$ were diluted three times with $0.1 \mathrm{M} \mathrm{HCl}$, saturated with $\mathrm{NaCl}$, and $50 \mu \mathrm{l}$ of a solution of deuterated isomers in $0.1 \%{ }^{2} \mathrm{HCl}$ in ${ }^{2} \mathrm{H}_{2} \mathrm{O}$ were added, followed by the addition of $0.1 \mathrm{ml}$ of a $0.03 \mathrm{M}$ solution of ascorbic acid as an antioxidant. This solution was extracted twice with $4 \mathrm{ml}$ of ethyl acetate with vigorous mixing for $5 \mathrm{~min}$. Phase separation was facilitated by centrifugation $(5 \mathrm{~min}$ at $2400 \mathrm{~g}$ ). Between the phases a gel layer was formed containing ca. $1 \mathrm{ml}$ of ehyl acetate and water. After the first extraction $3 \mathrm{ml}$ of ethyl acetate were available and after the second extraction $4 \mathrm{ml}$. The combined supernatants $(7 \mathrm{ml})$ were back-extracted into $2 \mathrm{ml}$ of phosphate buffer $(\mathrm{pH}$ 7.7) with vigorous mixing for $2 \mathrm{~min}$. The organic layer was aspirated.

\section{Aqueous acetylation}

Plasma back-extract. To the aqueous solution obtained as described above, $30 \mu \mathrm{l}$ of AA were added with continuous mixing for $1 \mathrm{~min}$. Then $0.5 \mathrm{ml}$ of 
STEP

Plasma

pre-treatment

Aqueous acetylation

(step I)

\section{PFB}

esterification

(step II)

\section{Anhydrous} acetylation (step III)
$5 \mu 1$ PFB-Br, $10 \mu 1$ TEA

$50 \mu l$ acetonitrile

$3 \mathrm{ml}$ ethyl acetate

$1 \mathrm{ml} 0.1 \mathrm{M} \mathrm{HCl}$

ADDITION

$2 \mathrm{ml} 0.1 \mathrm{M} \mathrm{HCl}$ saturated with $\mathrm{NaCl}$

$0.1 \mathrm{ml} 0.03 \mathrm{M}$ ascorbic acid

$0.05 \mathrm{ml}$ internal standard

$2 \times 4 \mathrm{ml}$ ethyl acetate

$2 \mathrm{ml} 1 M$ phosphate (pH 7.7)

$30 \mu l$ acetic anhydride

$0.5 \mathrm{ml}$ carbonate-phosphate buffer (pH 10.5)

$30 \mu \mathrm{l}$ acetic anhydride

$0.8 \mathrm{ml} 6 \mathrm{M} \mathrm{HCl}$

$2 \times 4 \mathrm{ml}$ ethyl acetate

$50 \mu l$ ethyl acetate

$50 \mu \mathrm{l}$ acetic anhydride

$10 \mu l$ triethylamine

$3 \mathrm{ml}$ ethyl acetate

$1 \mathrm{ml} 0.1 \mathrm{M} \mathrm{HCl}$

$50 \mu 1$ hexane

\section{PROCESS}

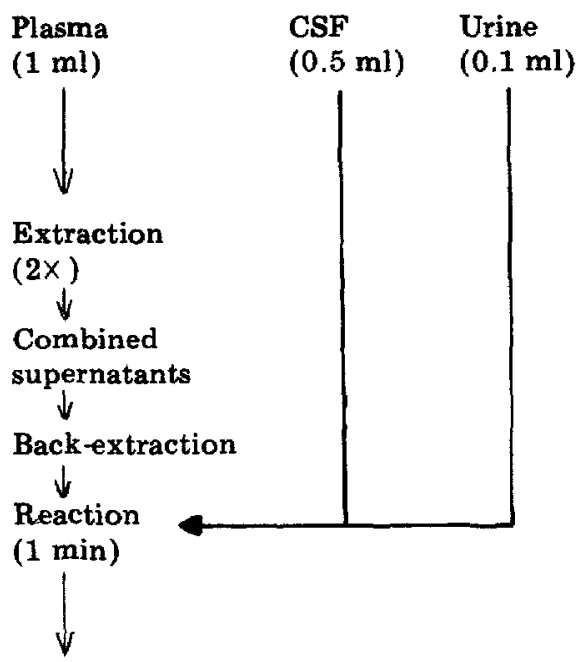

Reaction

(10 $\mathrm{min}$ )<smiles>[CH][CH]</smiles>

Extraction

(2x)

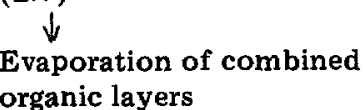

organic layers<smiles>C1CCC1</smiles>

Reaction

(5 min)

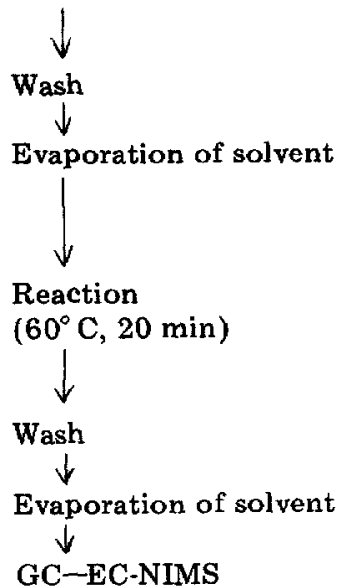

Fig. 1. Scheme of the analytical procedure for GC-EC-NIMS analysis of acidic catecholamine metabolites. TEA = triethylamine $; \mathrm{PFB}=$ pentafluorobenzyl. 
the phosphate - carbonate buffer and $30 \mu \mathrm{l}$ of AA were added. This mixture was allowed to react at room temperature for $10 \mathrm{~min}$.

CSF, urine and standard solutions (authentic samples, no pre-treatment necessary). Samples ( $0.5 \mathrm{ml}$ of $\mathrm{CSF}, 0.1 \mathrm{ml}$ of urine) were spiked with suitable amounts of deuterated isomers. Then $2 \mathrm{ml}$ of $1 M$ phosphate buffer ( $\mathrm{pH} 7.7$ ) were added and subsequently processed as described for plasma back-extracts.

\section{Preparation of PFB esters and anhydrous acetylation}

The aqueous reaction medium was acidified to $\mathrm{pH} 3$ with $0.8 \mathrm{ml}$ of $6 \mathrm{M} \mathrm{HCl}$. The derivatives formed were extracted twice with $4 \mathrm{ml}$ of ethyl acetate. The combined organic layers were evaporated with a stream of nitrogen at $60^{\circ} \mathrm{C}$. The residue was treated with $5 \mu \mathrm{l}$ of PFB-Br and $10 \mu \mathrm{l}$ of TEA in $50 \mu \mathrm{l}$ of acetonitrile for $5 \mathrm{~min}$ at room temperature [12]. Then $3 \mathrm{ml}$ of ethyl acetate were added and the solution washed with $1 \mathrm{ml}$ of $0.1 \mathrm{M} \mathrm{HCl}$. The organic layer was evaporated under nitrogen at $60^{\circ} \mathrm{C}$ and the residue treated with $100 \mu \mathrm{l}$ of a mixture of AA and TEA in ethyl acetate $(45: 10: 45, \mathrm{v} / \mathrm{v})$ at $60^{\circ} \mathrm{C}$ for 30 min. The reaction product was dissolved in $3 \mathrm{ml}$ of ethyl acetate and washed with $1 \mathrm{ml}$ of $0.1 \mathrm{M} \mathrm{HCl}$. The organic layer was evaporated and the residue stored until analysis. Before analysis, the residue was dissolved in $50 \mu l$ (plasma and CSF samples) or $1 \mathrm{ml}$ (urine samples) of hexane. A 2- $\mu$ l volume was placed on the falling needle and the solvent was evaporated.

\section{Recovery}

HVA-d $\mathrm{d}_{3}(9.88 \mu \mathrm{g})$, DOPAC- $\mathrm{d}_{3}(1.68 \mu \mathrm{g})$ and VMA-d $\mathrm{d}_{3}(4.88 \mu \mathrm{g})$ were derivatized as described for standards and subsequently dissolved in $40 \mathrm{ml}$ of ethyl acetate (reference solution). Of this solution, $50 \mu \mathrm{l}$ were used for recovery estimates. The yields of various steps in the procedure (Fig. 1) were determined by processing $11.9 \mathrm{ng}$ of HVA, $4.7 \mathrm{ng}$ of DOPAC and $7.1 \mathrm{ng}$ of VMA. The reference compounds were introduced into the procedure before each step to be investigated.

\section{RESULTS AND DISCUSSION}

In recent years, a wide variety of methods for GC-EIMS analysis of acidic CA metabolites in biological material have been described [4]. Only a limited number of these are suitable [21,22] and have been applied to biological samples [13] using GC-EC-NIMS. In these methods the metabolites were derivatized to their N,O,S-perfluoroacylcarboxyperfluoroalkyl esters.

In this work we propose the omission of N,O,S-perfluoroacylation for negative-ion analysis of these metabolites because it does not significantly improve the sensitivity and it will increase the background signal. Using a selective detector such as the EC-NIMS system, a marked reduction in the background might be expected if the non-relevant compounds remain undetected. The acidic CA metabolites contain phenolic hydroxy groups and a carboxy group; both may be selected to react with an electrophoric reagent. Esterification with PFB-Br was preferred, based on recent experiments with favourable EC-NIMS characteristics of PFB esters $[5,7-9,12]$. However, it appeared that this reagent also reacted to some extent with phenolic 
hydroxy groups [23], resulting in products of low volatility and difficult to identify. To prevent this side-reaction it was necessary to block this hydroxy group by acetylation prior to esterification. This problem was not reported by Shimamura et al. [5]. In their method, PFB esters of HVA and VMA were converted into their $\mathrm{O}$-trimethylsilyl (TMS) ethers. The rate of the reaction between $\mathrm{PFB}-\mathrm{Br}$ and phenolic $\mathrm{OH}$ will depend on the $\mathrm{pH}$ of the aprotic reaction medium. Their esterification conditions used (briefly, PFB-Br in acetone with carbonate as catalyst) may explain this contrast. We preferred a stronger catalyst (TEA) to ensure a quantitative yield [12] .

Acetylation of the phenolic hydroxy group had to be carried out in aqueous solution [14] because mixed anhydrides of HVA and DOPAC were formed by anhydrous acetylation. In addition to its blocking function, aqueous acetylation prevented dihydroxyphenyl metabolites from oxidative degradation and improved their recovery during organic solvent extraction.

\section{Methodology}

The proposed method, as outlined in Fig. 1, consists of a three-step derivatization scheme. It appeared to be essential that in steps II and III the excesses of reagents and by-products formed were removed by washing. In addition, contrary to earlier reports $[14,15]$, we observed a $10-20 \%$ acetylation of aliphatic hydroxy groups of VMA, DOMA and VLA in step I, making anhydrous acetylation in the third step obvious. The presence of the carboxyPFB group considerably reduced the reactivity of the aliphatic hydroxy group

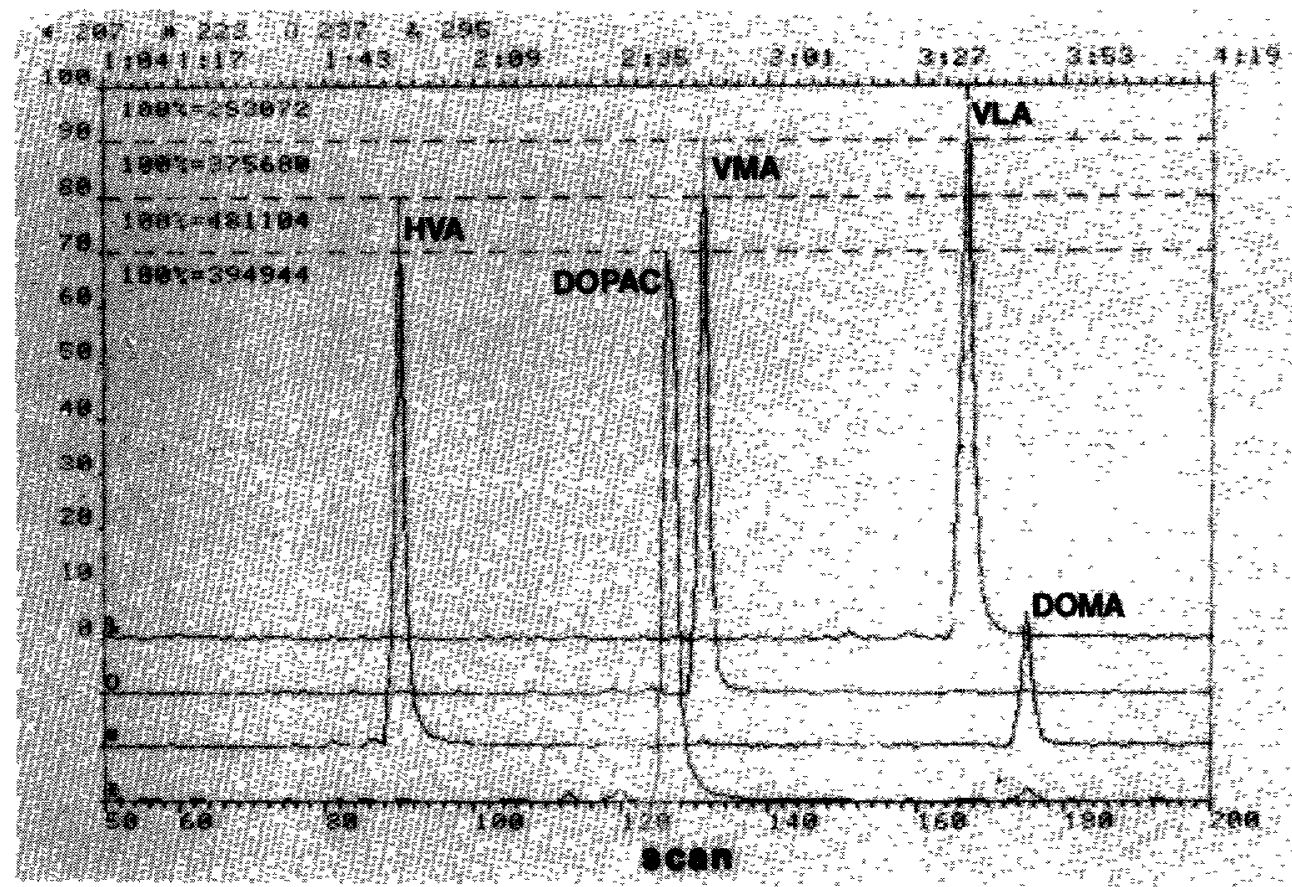

Fig. 2. Selected-ion recordings of standards, HVA, DOPAC, VMA, VLA and DOMA. Offset time axis, $2 \min 15 \mathrm{~s}$. 
towards acetic anhydride. Addition of a basic catalyst (TEA) markedly increased the rate of reaction so that at $60^{\circ} \mathrm{C}$ the acetylation was completed within $30 \mathrm{~min}$.

\section{Gas chromatography-mass spectrometry}

The AC-PFB derivatives of acidic CA metabolites showed good chromatographic characteristics. However, analysis at the $1-10 \mathrm{pg}$ on-column level required an extensively cleaned system. At this level the results might even be adversely affected by the presence of non-volatile residues due to insufficient clean-up in step II and III. The separation of the most prominent endogenous metabolites on the CPSIL-19 fused-silica capillary column is shown in Fig. 2.

\section{TABLE I}

MAIN CHARACTERISTICS OF ELECTRON-IMPACT MASS SPECTRA OF ACETYLPENTAFLUOROBENZYL DERIVATIVES OF ACIDIC CATECHOLAMINE METABOLITES

\begin{tabular}{lllllll}
\hline Compound & MW & \multicolumn{4}{l}{ Characteristic ions, $m / z$ (relative abundance) } \\
\hline HVA & 404 & $362(35), 181$ & $(32), 137(100)$ \\
VMA & 462 & $420(7), 222$ & $(14), 181$ & $(32), 153(100), 151$ & $(51)$ \\
DOPAC & 432 & $390(7), 348$ & $(55), 181$ & $(32), 123(100)$ & \\
VLA & 476 & $434(16), 374(100), 181$ & $(37), 137(56)$ & \\
DOMA & 490 & $448(4), 406$ & $(19), 208$ & $(28), 181 \quad(70), 139(100), 137(74)$ \\
\hline
\end{tabular}

The EI mass spectra are summarized in Table I. EIMS and PICIMS were used to confirm the identity of the derivatives formed. The EC-NI mass spectra (Fig. 3) consisted of ions arising from losses of $\mathrm{CH}_{2} \mathrm{C}_{6} \mathrm{~F}_{5}$ (ion a, Fig. 4) and $\mathrm{COOCH}_{2} \mathrm{C}_{6} \mathrm{~F}_{5}$ (ion b) from the ionized molecular species, respectively. In addition, the EC-NI mass spectrum of DOMA-AC-PFB showed an intense peak at $-m / z 223$, which corresponds to the expulsion of ketene from ion $b$. The abundance of $a$ and $b$ depended strongly on the molecular structure and the ion source temperature. High source temperatures favoured the formation of $b$ at the expense of a (Fig. 5) for all compounds except VLA. To prevent condensation during analysis a high source temperature $\left(\geqslant 225^{\circ} \mathrm{C}\right)$ was required. The observed increase in sensitivity for EC-NIMS versus EIMS was primarily due to an approximately two orders of magnitude higher ionization efficiency and secondly to lesser fragmentation. The gain in sensitivity obtained for the individual compounds is shown in Table II. The limits of detection of the indicated ions (Table II) using selected-ion monitoring in general exceeded $0.2 \mathrm{pg}$ on-column.

\section{Quantitation in biological samples}

Isolation of acidic CA metabolites from plasma samples was necessary for reliable DOPAC analysis. Otherwise, plasma phenylalanine (Phe) will occasionally disturb the recording of DOPAC ion traces. For CSF and urine this prepurification was not required because the ratio of the concentrations of DOPAC and Phe in these was much higher than that in plasma. 


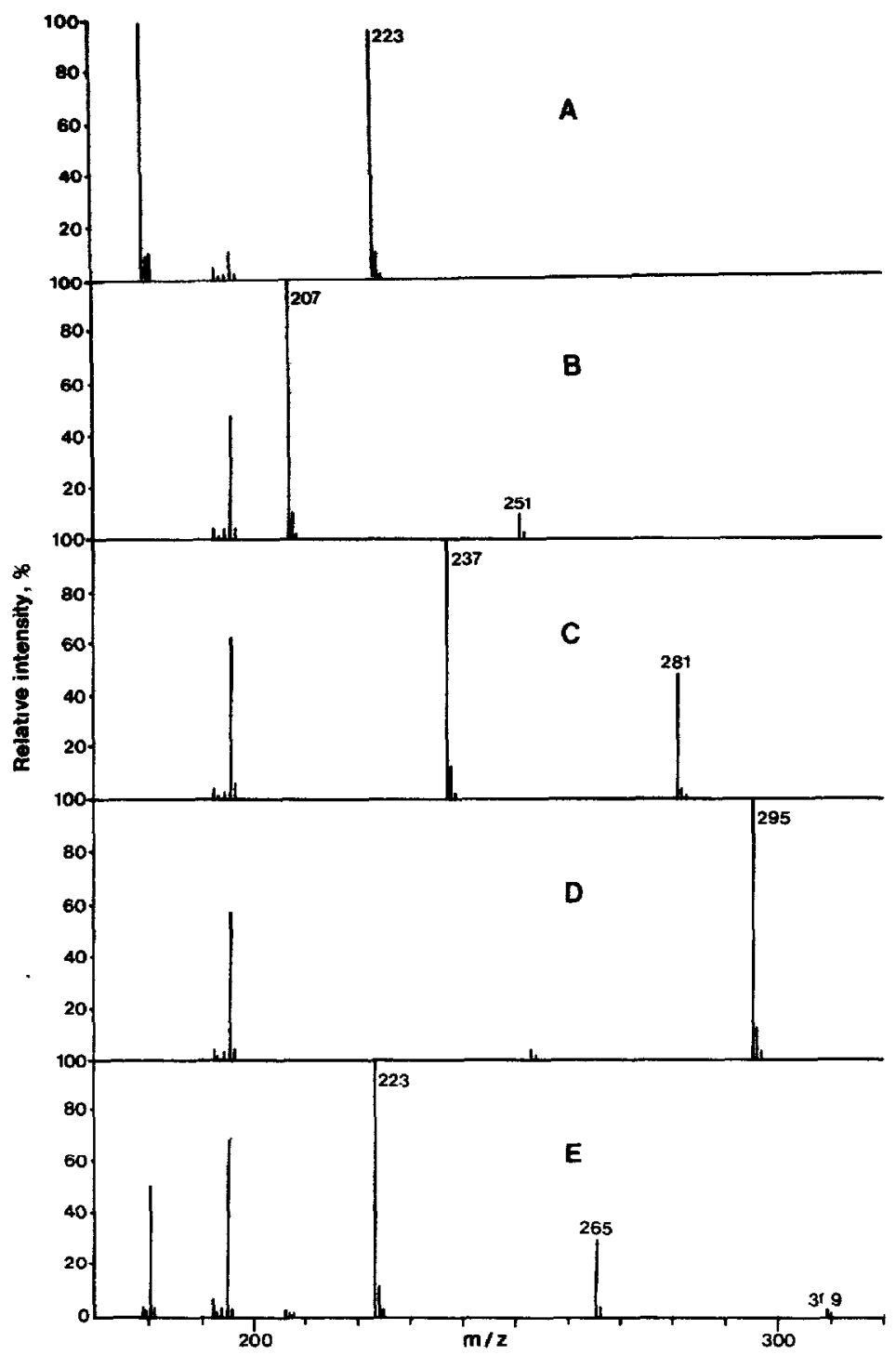

Fig. 3. Electron-capture detection-negative-ion mass spectra of acetylpentafluorobenzyl derivatives of (A) HVA, (B) DOPAC, (C) VMA, (D) VLA and (E) DOMA.

Various steps in the sample handling procedure were examined for the recovery of HVA, DOPAC and VMA in the nanogram range (6-10 $\mathrm{ng}$ ). As shown in Table III, saturation of the sample with $\mathrm{NaCl}$ (salting-out) improved the recovery of VMA. In addition, the presence of ascorbic acid (antioxidant) during extraction and back-extraction was necessary for the recovery of DOPAC. Using both salting-out and ascorbic acid, the recoveries of all three compounds were more than $90 \%$. The large amount of ascorbic acid added was not seen in the chromatogram.

The calculated partition constants of the AC derivatives of HVA, DOPAC and VMA for the system ethyl acetate-acidic medium $(\mathrm{pH}<3$ ) were 6.1 , 


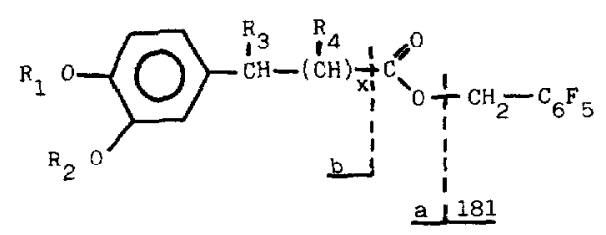

$\begin{array}{llllllll}\text { Compound } & x & \mathrm{R}_{1} & \mathrm{R}_{2} & \mathrm{R}_{3} & \mathrm{R}_{4} & \underline{a} & \underline{\mathrm{b}} \\ \text { HVA } & 0 & \mathrm{COCH}_{3} & \mathrm{CH}_{3} & \mathrm{H} & - & 223 & 179 \\ \text { DOPAC } & 0 & \mathrm{COCH}_{3} & \mathrm{COCH}_{3} & \mathrm{H} & - & 251 & 207 \\ \text { VMA } & 0 & \mathrm{COCH}_{3} & \mathrm{CH}_{3} & 0-\mathrm{COCH}_{3} & - & 281 & 237 \\ \text { DOMA } & 0 & \mathrm{COCH}_{3} & \mathrm{COCH}_{3} & 0-\mathrm{COCH}_{3} & - & 309 & 265 \\ \text { VLA } & 1 & \mathrm{COCH}_{3} & \mathrm{CH}_{3} & \mathrm{H} & 0-\mathrm{COCH}_{3} & 295 & 251\end{array}$

Fig. 4. General structure of acetylpentafluorobenzyl derivatives of acidic catecholamine metabolites and their most prominent fragments (ions a and b) under ECNI.

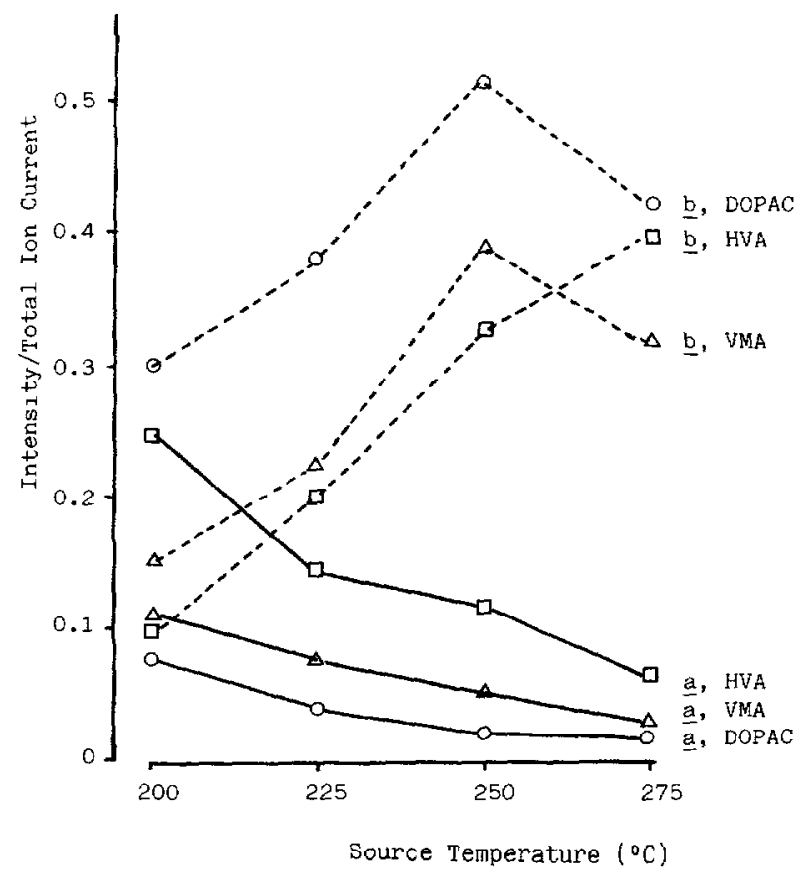

Fig. 5. Influence of source temperature on fragmentation. $a=\left[\mathrm{M}-\mathrm{CH}_{2} \mathrm{C}_{6} \mathrm{~F}_{5}\right]^{-} ; \mathrm{b}=$ $\left[\mathrm{M}-\mathrm{CO}_{2} \mathrm{CH}_{2} \mathrm{C}_{6} \mathrm{~F}_{5}\right]^{-}$.

8.6 and 4.3, respectively. Two-fold extraction with a phase ratio of $4: 3$ $\left(V_{\text {org }} / V_{\text {aq }}\right)$ provided quantitative recoveries $(>99 \%)$ of the acetyl derivatives. Extractions following PFB treatment and anhydrous acetylation were also quantitative. 
TABLE II

COMPARISON OF THE SENSITIVITY OF ACETYLPENTAFLUOROBENZYL DERIVATIVES OF ACIDIC CATECHOLAMINE METABOLITES ANALYSED BY EIMS AND EC-NIMS

\begin{tabular}{llll}
\hline Compound & \multicolumn{2}{l}{ Analysed ion } & $\begin{array}{l}\text { Intensity ratio, } \\
\text { EC-NIMS/EIMS }\end{array}$ \\
\cline { 2 - 3 } & EIMS & EC-NIMS & \\
\hline HVA & 362 & -223 & 420 \\
DOPAC & 348 & -207 & 280 \\
VMA & 420 & -237 & 715 \\
VLA & 374 & -295 & 90 \\
DOMA & 406 & -223 & 295 \\
\hline
\end{tabular}

TABLE III

RECOVERY ESTIMATES FOR SOME STEPS OF THE PROCEDURE

\begin{tabular}{llll}
\hline Step & \multicolumn{3}{l}{ Recovery (mean, $n=3)(\%)$} \\
\cline { 2 - 4 } & $\begin{array}{l}\text { HVA } \\
(11.9 \mathrm{ng})\end{array}$ & $\begin{array}{l}\text { DOPAC } \\
(4.7 \mathrm{ng})\end{array}$ & $\begin{array}{l}\text { VMA } \\
(7.1 \mathrm{ng})\end{array}$ \\
\hline Back-extraction without ascorbic acid & 96 & 47 & 94 \\
Extraction plus back extraction: & & & \\
$\quad$ Without NaCl and ascorbic acid & 82 & 10 & 45 \\
$\quad$ Standard procedure & 97 & 88 & 105 \\
Extraction of O-acetyls & 99 & 100 & 99 \\
Overall recovery & 94 & 90 & 86 \\
\hline
\end{tabular}

The precision of the method was determined by analysing five plasma samples individually. The relative standard deviations obtained were 1.8, 1.6 and $4.5 \%$ for HVA, DOPAC, and VMA, respectively.

\section{Control values}

Plasma. The method was applied to plasma samples drawn from non-fasting, healthy adults. The levels of HVA and DOPAC obtained were found to be $12.1 \pm 6.7$ and $3.0 \pm 1.3 \mathrm{ng} \mathrm{ml}^{-1}$, respectively (mean \pm S.D., $n=10$ ).

In another series of randomly collected plasma samples from healthy adults, which were stored at $-20^{\circ} \mathrm{C}$ for several weeks or months, the HVA and VMA levels were 11.97 and $7.26 \mathrm{ng} \mathrm{ml}^{-1}$, respectively (pooled plasma, $n=20$ ). The DOPAC level appeared to be very low $\left(0.3 \mathrm{ng} \mathrm{ml}^{-1}\right)$, probably owing to oxidation during storage.

These results were in good agreement with normal values obtained with other techniques (Table IV).

CSF. HVA, DOPAC and VMA were determined in randomly collected CSF samples from hospitalized adults, not suffering from neurological or mental diseases. The concentrations obtained were HVA, $34.3 \pm 21 \mathrm{ng} \mathrm{ml}^{-1}$ and DOPAC $0.91 \pm 0.34 \mathrm{ng} \mathrm{ml}^{-1}$ (mean \pm S.D., $n=14$ ). The correlation 


\section{TABLE IV}

COMPARISON BETWEEN THE LEVELS OF HVA, DOPAC AND VMA IN PLASMA OR SERUM OF NORMAL ADULTS, OBTAINED BY DIFFERENT WORKERS AND WITH DIFFERENT TECHNIQUES

\begin{tabular}{|c|c|c|c|c|}
\hline \multirow[t]{2}{*}{ Reference } & \multirow[t]{2}{*}{ Method } & \multicolumn{3}{|c|}{ Level $($ mean \pm S.D. $)\left(n g \mathrm{ml}^{-1}\right)$} \\
\hline & & HVA & DOPAC & VMA \\
\hline 3 & GC-EIMS & $11.7 \pm 1.9$ & $1.03 \pm 0.19$ & $12.4 \pm 1.3$ \\
\hline 24 & GC-EIMS & $11.3 \pm 4.2$ & - & $5.9 \pm 2.2$ \\
\hline 25 & HPLC & $9.8 \pm 0.5$ & - & - \\
\hline 26 & HPLC & $12.0 \pm 3.8$ & - & $9.0 \pm 4.0$ \\
\hline 27 & HPLC & $12.9 \pm 3.2$ & $2.02 \pm 0.28$ & - \\
\hline This work & GC-EC-NIMS & $12.1 \pm 6.7$ & $2.96 \pm 1.27$ & 7.3 \\
\hline
\end{tabular}

between HVA $(y)$ and DOPAC $(x)$ was $y=52.2 x-10$ with a correlation coefficient $r=0.84(n=12)$. In a pool of equal volumes of these samples $(n$ $=14$ ) the following values were obtained (means of duplicate data): HVA $34.2 \mathrm{ng} \mathrm{ml}^{-1}$, DOPAC $0.99 \mathrm{ng} \mathrm{ml}^{-1}$ and VMA $1.04 \mathrm{ng} \mathrm{ml}^{-1}$. VMA measurement was included in the pooled CSF samples, although this metabolite is not relevant for studies on the dopamine metabolism in brain. The CSF levels obtained did not agree well with those given by Karoum [3] (HVA $51 \pm 8$ $\mathrm{ng} \mathrm{ml}{ }^{-1}$, DOP AC $3 \pm 1.6 \mathrm{ng} \mathrm{ml}^{-1}$ and VMA $0.46 \pm 0.18 \mathrm{ng} \mathrm{ml}^{-1}$ ), whereas the HVA value in CSF was in accord with that reported by Vogt et al. [28] (HVA $30.9 \mathrm{ng} \mathrm{ml}^{-1}$ ) and Bottiglieri et al. [29] (HVA $29.5 \mathrm{ng} \mathrm{ml}^{-1}$ ).

\section{CONCLUSION}

The pcr-O-acctylcarboxy-PFB derivatives of acidic CA metabolites have been shown to be very suitable for both qualitative and quantitative GC-EC-NIMS analysis. The EC-NI mass spectra contained abundant and structurally diagnostic anions. The strongly electrophoric carboxy-PFB group provided a high ionization efficiency, which allowed profiling at the sub-nanomoles per litre level of several acidic catecholamine metabolites in biological materials.

\section{REFERENCES}

1 P.S. Doshi and D.J. Edwards, J. Chromatogr., 210 (1981) 505.

2 F.A.J. Muskiet, Determination of Catecholamine and Catecholamine (Precursor) Metabolites in Biological Fluids and Their Clinical Applications, Thesis, University of Groningen, Groningen, 1979.

3 F. Karoum, in S. Parvez, T. Nagatsu, I. Nagatsu and H. Parvez (Editors), Methods in Biogenic Amine Research, Elsevier, Amsterdam, 1983, pp. 237-250.

4 K.F. Faull and J.D. Barchas, in S. Parvez, T. Nagatsu, I. Nagatsu and H. Parvez (Editors), Methods in Biogenic Amine Research, Elsevier, Amsterdam, 1983, pp. 189-230.

5 M. Shimamura, S. Kamada, T. Hayasha, H. Naruse and Y. Iida, J. Chromatogr., 374 (1986) 17. 
6 J.T. Martin, J.D. Barchas and K.F. Faull, Anal. Chem., 54 (1982) 1806.

7 K.A. Wadell, I.A. Blair and J. Welby, Biomed., Mass Spectrom., 10 (1983) 83.

8 H. Miyazaki, M. Ishibashi, H. Takayama, K. Yamahita, I. Suwa and M. Katori, J. Chromatogr., 289 (1984) 249.

9 L.J. Roberts, J. Chromatogr., 287 (1984) 155.

10 H. Schweer, J. Kammer and H. Seyberth, J. Chromatogr., 338 (1985) 273.

11 G.K.-C. Low and A.M. Duffield, Biomed. Mass Spectrom., 11 (1984) 223.

12 R.J. Strife and R.C. Murphy, J. Chromatogr., 305 (1984) 3.

13 P.L. Wood, Biomed. Mass Spectrom., 9 (1982) 302.

14 S. Takahishi, D.D. Godse, J.J. Warsh and H.C. Stancer, Clin. Chim. Acta, 81 (1977) 183 .

15 J.J. Warsh, D.D. Godse, S.W. Cheung and P.P. L1, J. Neurochem., 36 (1981) 893.

16 D.C. Jimerson, S.P. Markey, J.A. Oliver and I.J. Kopin, Biomed. Mass Spectrom., 8 (1981) 256.

17 A.P.J.M. de Jong and C.A. Cramers, J. Chromatogr., 276 (1983) 267.

18 A.P.J.M. de Jong, J. High Resolut. Chromatogr. Chromatogr. Commun., 4 (1981) 125.

19 R.M. Kok, A.P.J.M. de Jong, C.J. van Groeningen, G.J. Peters and J. Lankelma, J. Chromatogr., 343 (1985) 59.

20 F.A.J. Muskiet, H.J. Jeuring, C.G. Thomassen, J. van der Meulen and B.G. Wolthers, J. Labelled Compd. Radiopharm., 14 (1978) 497.

21 S.P. Markey, A.J. Lewy and R.W. Colburn, in A.P. De Leenheer (Editor), Quantitative Mass Spectrometry in Life Sciences II, Proc. 2nd Int. Symp., Ghent, June 13-16, 1978, Elsevier, Amsterdam, 1978, p. 17.

22 S. Takashi, M. Yoshioka, S. Yoshieu and Z. Tamura, J. Chromatogr., 145 (1978) 1.

23 F.K. Kawahara, Anal. Chem., 40 (1968) 1009.

24 F.A.J. Muskiet, G.T. Nagel and B.G. Wolthers, Anal. Biochem., 109 (1980) 130.

25 P.Q. Haris, N.G. Bacopoulos and S.J. Brown, J. Chromatogr., 309 (1984) 379.

26 D.H. Hunneman, Clin. Chim. Acta, 135 (1983) 169.

27 A. Minegishi and T. Ishizaki, J. Chromatogr., 308 (1984) 55.

28 W. Vogt, K. Jacob, A.-B. Ohnesorge and G. Schwertfeger, J. Chromatogr., 199 (1980) 191.

29 T. Bottiglieri, C.K. Lim and T.J. Peters, J. Chromatogr., 311 (1984) 354. 